\title{
Healing in Herero culture and Namibian African independent churches
}

\begin{tabular}{|c|c|}
\hline \multicolumn{2}{|c|}{$\begin{array}{l}\text { Authors: } \\
\text { Selaelo T. Kgatla } \\
\text { Jinho Park }{ }^{1}\end{array}$} \\
\hline \multicolumn{2}{|c|}{$\begin{array}{l}{ }^{1} \text { Department of Science of } \\
\text { Religion and Missiology, } \\
\text { Faculty of Theology, } \\
\text { University of Pretoria, } \\
\text { South Africa }\end{array}$} \\
\hline \multicolumn{2}{|c|}{$\begin{array}{l}\text { Correspondence to: } \\
\text { Selaelo Kgatla }\end{array}$} \\
\hline \multicolumn{2}{|c|}{$\begin{array}{l}\text { Email: } \\
\text { thias.kgatla@up.ac.za }\end{array}$} \\
\hline \multicolumn{2}{|c|}{$\begin{array}{l}\text { Postal address: } \\
\text { Department of Science of } \\
\text { Religion and Missiology, } \\
\text { Faculty of Theology, } \\
\text { University of Pretoria, } \\
\text { Lynwood Road, Hatfield } \\
\text { Campus, Pretoria }\end{array}$} \\
\hline \multicolumn{2}{|c|}{$\begin{array}{l}\text { Dates: } \\
\text { Received: } 03 \text { Apr. } 2015 \\
\text { Accepted: } 29 \text { Apr. } 2015 \\
\text { Published: } 14 \text { Sept. } 2015\end{array}$} \\
\hline \multicolumn{2}{|c|}{$\begin{array}{l}\text { How to cite this article: } \\
\text { Kgatla, S. \& Park, J., 2015, } \\
\text { 'Healing in Herero culture } \\
\text { and Namibian African } \\
\text { independent churches', } \\
\text { HTS Teologiese Studies/ } \\
\text { Theological Studies 71(3), } \\
\text { Art. \#2922, } 9 \text { pages. http:// } \\
\text { dx.doi.org/10.4102/hts. } \\
\text { v71i3.2922 }\end{array}$} \\
\hline \multicolumn{2}{|c|}{$\begin{array}{l}\text { Copyright: } \\
\text { (C) 2015. The Authors. } \\
\text { Licensee: AOSIS } \\
\text { OpenJournals. This work is } \\
\text { licensed under the Creative } \\
\text { Commons Attribution } \\
\text { License. }\end{array}$} \\
\hline \multicolumn{2}{|l|}{ Read online: } \\
\hline 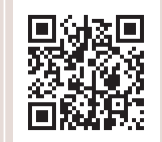 & $\begin{array}{l}\text { Scan this QR } \\
\text { code with your } \\
\text { smart phone or } \\
\text { mobile device } \\
\text { to read online. }\end{array}$ \\
\hline
\end{tabular}

The current phenomenon of Namibian African Independent Churches (NAICs) draws attention from various people in civil society in Namibia. Although the ministries of NAICs are engaged with activities which are unusual for Christian churches, such as healing the people, fighting against evil spirits and power, performing certain rituals, prophesying and leading the worship services with African Traditional Religion (ATR) as a frame of reference in 21st century, they do have a very big influence on various aspects of society in Namibia, which cannot be ignored. This is because those activities are familiar to the everyday lives of Africans and in touch with their culture. With regards to this, this article focuses on the causes of integration or harmony between the Herero culture and the NAICs.

\section{Introduction}

\section{African Independent Churches in Namibia}

The first Namibian African Independent Church ${ }^{1}$ (NAIC) was established by the Herero tribe. This happened because the Herero members of the Rhenish Mission Church (RMC) $)^{2}$ wanted to have their own church that would reflect their culture and that would be ministered by Herero leadership. At that time, Herero members of the RMC felt that they were victims of racial discrimination, that there was ambiguity surrounding the finances of their church and that their Herero evangelists were being treated unjustly. The Herero then seceded from RMC and established their own independent church in 1955, which was called the Oruuano Church, or the Protestant Unity Church (PUC) (Breure 1999:40; Buys \& Nambala 2003:182). Another cause of this secession was paternalism in RMC's ministry (Breure 1999:28-33).

After this secession, the Namibians established their churches in Windhoek but affiliated them to St John's Apostolic Faith Mission in South Africa (SJAFMSA), one of the prominent African Independent Churches (AICs) founded by Cristina Mokotoli Nku in 1952 (Amanze 1994:265). Only Herero people founded those churches in Windhoek. In this context, the churches were Hereroised, affected by the tribal culture of the Herero. Those churches which had been enculturated were called the 'Herero Church' in Namibia (Turner 1979:84). Since then, NAICs have proliferated.

\section{Challenges of the study}

This article attempts to make inroads into the question of African Independent Churches by using the healing rituals of the Namibian African Independent Churches (NAICs) and their relationship with African Traditional Religions as an example. The healing rituals of these churches are good examples of how this issue affects the lives of Africans because healing is a very important aspect of the African Independent Churches (AICs) in Southern Africa and also a significant driving force behind their proliferation.

Due to the lack of qualitative research investigating this particular issue, this article will be based on case studies of the healing rituals conducted in two of the principal NAICs, which are SJAFMSA-related churches, namely the St John's Apostolic Faith Mission in Namibia (SJAFMN) of Archbishop P.K.D.U. Tjijombo and St Joel Apostolic Healing Mission Church in Africa (SJAHMCA) of Archbishop T.K. Pura. These churches could be described as healing-centred. The other necessary empirical data, which was collected through participatory observation performed by the author of this article, will be used as references from time to time.

\footnotetext{
1.The terms Namibian African Independent Churches (NAICs, or NAIC as the singular) and African Independent Church in Namibia (AICN) are used as synonyms for the Namibian African Independent Church. It will be used as singular or plural according to the occasion.

2.The Rhenish Missionary Society (RMS) established the Rhenish Mission Church (RMC). The RMS was established by the Elberfeld Missionary Society (EMS) and Barman Missionary Society (BMS), which were in what used to be called Prussia. They were combined in 1828. They have been involved in missionary work in Windhoek since 1842 (Buys \& Nambala 2003:15-17).
} 
This research was done in Katutura in Windhoek, the capital city of Namibia. According to the Namibia 2011 population and housing census main report, the population of Windhoek is 342 141 and the literacy rate is $97 \%$ amongst people over the age of 15 years (Namibia 2011 population and housing census main report 2015).

\section{Healing}

Healing is very important in the everyday lives of African people. West (1975:49) mentions that South African people in Soweto consider the 'healing abilities' of the church leaders as an important factor when they join a church in South Africa. A very similar situation exists in Namibia. Most of the NAICs have healing sessions, not only during the service, but also on many other occasions.

The African idea of healing goes beyond the boundaries set by Western thought on healing. When Africans heal people, they fight against 'African diseases' (Maboea 2002:48) and possibly even political circumstances, for example apartheid (Thomas 1997:19). Whilst Westerners fight against diseases by considering blood tests, viruses, germs, bacteria and the reading of scans, Africans fight against evil powers, magic, visitations and broken harmony or communal relationships. Whilst Westerners heal with scientifically approved medicines, AICs heal with traditionally approved natural materials which have been prayed over. Whilst Westerners heal individuals, Africans heal families and communities. Healing in the AICs is not a finite but a holistic process which attempts to encourage progress on many levels, moving across the borders between the living and the dead, spirituality and physicality and the material domains involved in the patients' lives (Dube, Shoko \& Hayes 2011:176; Maboea 2002:129). Hence, the healing experience reveals the hermeneutical basis of a holistic soteriology of the AICs with 'biblical revelation' from the prophets, Christ Himself and the apostles in the Bible (Anderson 2000:138).

\section{Healing: SJAFMN3}

In the case of SJAFMN, water is an important vehicle for healing. $\mathrm{Nku}$, the founder of SJAFMSA, used to heal her church members with water (Amanze 1994:267). SJAFMN follows in the footsteps of $\mathrm{Nku}$ in this respect.

SJAFMN uses Holy Water (Omeva Omajapuke) on most of its Sunday services throughout the year. During the normal procedure of the worship service, the Holy Water is shared before church members make their offerings. Archbishop Tjijombo says that ' $[t]$ he Holy water is just water, mixed with no other substances, and it is just prayed over in Jesus name'.

The church members of SJAFMN understand that this water is merely ordinary water over which a prayer has been said. However, they regard this water as a precious substance, containing the power of God, and they believe that it can heal the sick and protect them from evil power and so forth. Generally, the church members bring a container filled with water to church every Sunday and put it in front of the main entrance of the church building so that the church officials can pray over the water. When the water has been prayed over, it turns into 'Holy Water', and it is then used as such.

SJAFMN strongly believes that, when they pray over water, God puts some of his divine power into the water. The holy water is used for personal, communal and ceremonial purposes such as healing, purifying and chasing away evil spirits. Church members and communities usually use the Holy Water by drinking it, sprinkling it and bathing themselves with it. Archbishop Tjijombo performs these rites with Holy Water in his ministry on the basis of Exodus 15:22-26 and John 2:1-11 in the Bible. However, it is difficult to understand why these Bible verses have been interpreted as encouraging the use of Holy Water in this way.

\section{Healing: SJAHMCA4}

Healing is a very important aspect of SJAHMCA's ministry. However, the healing aspect of SJAHMCA's ministry is different from that of SJAFMN. SJAHMCA does not use the same substances for healing the sick as SJAFMN. SJAHMCA and SJAFMN also do not perform the same rituals as part of their healing ministries.

SJAHMCA performs healing rituals for sick people at any time, both during its services and outside of them. The church members and the other people involved in the church regard Archbishop T.K. Pura as a faith healer.

In accordance with a prophecy by one of their founders and members, St. Joel performs the following rituals: They heal with medicine 'from pharmacies' (Western medicine), with holy ashes from trees and with animal dung, salt, fresh milk, candles and vinegar (Article 2.8). They also offer sacrifices of cattle, sheep, goats, doves, sunflower oil and olive oil (Article 2.9).

Archbishop T.K. Pura uses the healing substances as prescribed by the above church constitution. Most of the substances mentioned in the constitution are referred to in the Bible. Archbishop Pura employs certain biblical references, which are quoted below. Each different substance would be applied for its own purposes.

Healing materials and their usages in SJAHMCA: Holy ashes (Omuti Omujapuke): Numbers 19:9-10: The ash is from a tree called Omumborombonga. Herero people regard this tree as sacred. According to the Herero's oral tradition, the first Herero people came from the Omumborombonga tree (Kandovazu 2009:16). Thus, it is the tree of the origin of the Herero tribe. To create the ashes, the Herero cut-off the roots of the Omumborombonga and smash or burn them.

4.T.K. Pura, interviewed by Jinho Park, SJAHMC, Windhoek, Namibia, 04 September 2013. 
The ashes are used to bless pregnant women. When a woman is pregnant, she has to take a bath with water into which the ash was mixed. Vinegar is not added to the mixture in order to allow the woman to drink from this water as well. A woman is rarely required to drink the ash water for a normal birth. However, if a pregnant woman is unwell, she should take a bath with the water mixed with vinegar, milk, salt and the ash. The ash is also used to prevent problems with the scars resulting from C-sections by repeatedly applying the ash to the scar.

Salt (omongua): 2 Kings 2:19-22: Salt is one of the most significant healing substances for SJAHMCA. It is used as a medicine based on what Elisha had done at Jericho $(2 \mathrm{Kn}$ 2:19-22). Jericho had a serious problem with their water. When the men of Jericho told Elisha about this problem in their city, the Lord healed it through Elisha with salt.

Milk (omaihi): 1 Peter 2:2: Milk is used to keep bad luck away from people. Some people dream of washing their bodies with milk. After waking, they then set about washing themselves with milk to keep away bad luck. Milk is used to chase away the power of darkness, which causes bad luck. However, it is also used to call for good luck. Before the milk is used, it needs to be mixed with water. When it is mixed well, it will be given to sick or troubled people to wash their bodies. When a woman is barren, she has to bathe in milk.

Candle (erambe): Matthew 5:14-16: The function of the candle is identical to that of the lamp in Matthew 5:14-16. Here, the prayer, the light and the candle carry the connotative meaning of the power of God, which is able to get rid of problems or evil powers. As the people light a lamp, the lamp gives light to everyone (v. 15). Where there is light, the darkness will disappear. Thus, sick or troubled people should light the candle by themselves (v. 16) so that they may remember that they themselves should shine to get rid of the darkness.

In the same way, when people pray for healing someone, the person's problem will be solved as the darkness disappears. The darkness represents an evil power that has caused that person's problem. That is why people who have a problem must light a candle to chase the problem or evil spirit away from them. Thus, people have to light and hold the candle with both hands and concentrate on its light so that they themselves may not forget to keep on shining like the candle. They believe fervently that prayer removes the problems or the negative power of darkness from sick or troubled persons. A candle is used during the services as well.

Vinegar (asyna): Vinegar is only used for stomach pain and other stomach-related problems, for example gastroenteritis and dyspepsia. It should be mixed with water, and the patients must drink it for their ailments. However, vinegar is never prescribed to a person who is HIV-positive or has high blood pressure. The prophets know that this will weaken the sick person and may even cause death. When people drink it, they normally suffer severe diarrhoea. This would be similar to what we would call a laxative or therapy to cleanse the colon.

Water (Omeva): John 2:1-11: Water is an essential substance that is used to mix all other substances together. When the substances are mixed with water, the church officials or healers pray over the water. Water is life itself. There are two types of water that SJAHMCA uses for healing in its church: They use ordinary water from a tap, which is considered to be more powerful if it has been prayed over, turning it into Holy Water. They also use water from the sea, which is considered to be special. Normal water is used for healing the people in general. However, the members of SJAHMCA think that the sea water is more powerful in healing.

\section{Healing ritual procedure: SJAHMCA5}

A female member of SJAHMCA required a consultation with Pura. She needed Pura to help her daughter. Her daughter was very sick (suffering from bad luck), and this was affecting her studies. She wanted Pura to help her daughter so that her daughter would be healed and be promoted to the next grade at school. Most consultations and healings are held at SJAHMCA in Katutura, Windhoek. The procedure of the healing ritual for this particular case is described below:

- scheduling a consultation with the sick or troubled person

- consultation with the person at SJAHMCA

- diagnosis and prescription

- Pura: taking water from the tap in the church yard

- Pura, person in need, and mother: sitting with the water next to the altar in the church building

- person in need: inhaling incense smouldering from thin aroma sticks

- Pura: putting the ash (omuti) into the water and praying over it

- Pura: pouring the milk over the hands of the person in need seven times

- person in need: taking the milk and washing her face seven times

- Pura: praying for her promotion by laying his hand on her head

- person in need: holding two candles whilst Pura is praying for her

- person in need: taking the water mixed with milk and ash to bathe

- person in need: bathing the whole body with the mixed water that had been prayed over

- person in need: returning to the seat after the bath

- Pura: praying for the patient again and completing the ritual.

However, if the person is not healed, then a sacrifice will be made as follows:

- The healer will request her to bring a sheep, some ordinary flour, olive oil or any appropriate sacrifice to church.

5.Observed by Jinho Park, SJAHMCA in Katutura, Windhoek, 05 September 2013. 
- The healer will burn and collect the ash from this sacrifice so that the person in need of help can bathe in it.

- Although the procedure described above is clearly based on a completely different set of ideas and assumptions than that of Western medicine, the procedure that is followed is similar to that of a medical doctor in many ways. Either case involves methodical adherence to a prescribed set of steps, a healer (who is recognised by his community as being skilled healer) giving a person in need careful thought and consideration, a diagnosis of sorts and a reassessment of the situation after treatment.

Aside from the two candles, Archbishop Pura used various substances in this healing ritual such as aroma sticks for incense, ash, milk, two candles and water. In the last part of this ritual, the patient took a bath in the water mixed with those substances. By considering the substances that he applied, we can interpret this ritual as an attempt to heal both the body and spirit of the woman's daughter by preventing bad luck and evil power from affecting her so that she would be promoted to the next grade at school by the power of God. It could be said that this was a holistic healing procedure.

\section{Animal sacrifice (ombunguhiro): SJAHMCA6}

The unpublished Constitution of SJAHMCA 2011 specifies that this church offers sacrifices of cattle, sheep, goats, doves and sunflower and olive oil (Article 2.9). Sacrificial offerings are crucial to the lives of the saints in Namibian AICs. According to the Archbishop, T. Pura, SJAHMCA performs animal sacrifices to honour that which is written in the Bible. It is typical of most of the AICs in Namibia that they interpret the Bible in a very literal way. Thus, since this church was established, SJAHMCA have been performing these sacrifices practically as described in the Bible.

The sacrificial offerings are generally performed during the Efeste. ${ }^{7}$ Efeste, in fact, is the key ministry of the AICs in Namibia, and it helps to sustain the faith lives of the members and keeps them involved with church concerns. However, animal sacrifices remain an intractable obstacle, preventing the so-called mainline churches from understanding the AIC. Unless the obstacle is overcome, the two church groupings will never find a way out of this regrettable situation in Africa. It is crucial that this issue be resolved.

Whenever SJAHMCA performs their rituals, they do it with reference to sections of the Bible, ${ }^{8}$ which support those rituals. Ombunguhiro is performed on the grounds of Leviticus 1-5, James 5:13 and Hebrews 5:1-6 and 9:18-22.

\section{T.K. Pura, interviewed by Jinho Park, SJAHMCA, 04 September 2013}

7.'Efeste' is a Herero word meaning 'feast' or 'party'. It is also sometimes called 'omukandi', but 'omukandi' actually refers more specifically to a wedding feast. In fact, SJAHMCA prefers to call it 'efeste', but SJAFM in Namibia calls it 'omukand?' To the AlCs in Namibla, there is no significant difference in the meaning of these terms. The term seems to have been adopted either from 'fees' in Afrikaans or from 'festival' in English, or from both of them.

8.The Bible verses cited in this part are from the archbishop T.K. Pura of SJAHMCA.
In the case of SJAHMCA, animal sacrifices are performed for specific purposes. According to Archbishop Pura of SJAHMCA, the purposes of animal sacrifice vary in accordance with Efeste in different seasons.

Firstly, they perform ombunguhiro to thank God for the exodus from the desperate life-situations that they have experienced and for all that God has done for his people. Exodus 12:29-42 and Deuteronomy 16:1-8 are used as precepts for such instances of animal sacrifice. Animal sacrifice is also used to thank God for the salvific works of Jesus Christ on the cross, as per the example set in John 13:1. Animal sacrifices for these reasons are performed during the Easter Efeste.

Secondly, when the church has a patient in a critical condition, ombunguhiro will be performed to heal the patient. SJAHMCA will perform this ritual at any time of year in order to heal a person in need, regardless of whether or not an Efeste is being held at that time. On the grounds of James 5:13, SJAHMCA acknowledges that the church is responsible for healing its sick members. The members of SJAHMCA, as Herero, are already familiar with the slaughtering of animals, which they have to perform on other occasions (Kandovazu 1968:11-13) like the people from the Old Testament in the Bible. The reason for this is that the Herero are traditionally semi-nomadic cattle farmers, who depend on cattle for their livelihood. Although the effects of Western medication are good, members of SJAHMCA want to be healed in accordance with the holistic, traditional healing methods with which they are accustomed, in other words, both physically and spiritually. When they heal the sick, they also want to see if there is any reason besides physical sickness that might cause the sick person to be sick. Such reasons can include an evil spirit, a broken relationship with God or ancestors, ${ }^{9}$ magic, and so forth, and its aim is to prevent the sick person from passing on any of these maladies to others. If one of these things are found to be causing a person to be sick, ombunguhiro will heal the person. For these reasons, ombunguhiro is performed if the sick church members give their consent to the church.

Thirdly, SJAHMCA performs the ombunguhiro to recall the founding Archbishop Kandovazu and the history of SJAHMCA. This takes place during the Efeste in November so that the numerous church members may hear how, where and when the church of SJAHMCA had been established by the founding members. They also hear who named the church and about the powerful ministries that Archbishop Kandovazu undertook. Then the Archbishop of SJAHMCA reads from the book of 2 Kings 2:1-17. It is about Elijah and Elisha. It seems that the Bible verses they read are not directly linked to the purpose of ombunguhiro and omukandi. Nevertheless, it is crucial to remind the church members that the current Archbishop of SJAHMCA has succeeded the founding Archbishop, and he has inherited his power and

9.Sacrifice is also a method in which to communicate with the ancestors and a way to resolve any damaged relationships with the ancestors in Africa (Prozensky \& De Gruchy 1995:21-23) 
also the authority to continue with the church ministry on the founding Archbishop's behalf. Thus, during this Efeste, new members of SJAHMCA must visit the graveyard of the founding Archbishop so that they can see where he is buried. This might be to demonstrate that the people of SJAHMCA observe the rules of their church and know the important events in its history.

Lastly, animal sacrifices are made to cleanse orutu [the body itself], the transgressor's body ( $\mathrm{Nm} \mathrm{6:11).} \mathrm{For} \mathrm{instance,} \mathrm{if}$ someone murdered anyone or caused the death of anybody else, the members of SJAHMCA believe that the ominous shadow or the invisible dirt of the deceased affects the murderer. Then the ombunguhiro will be performed in order to cleanse the murderer's body. This sacrifice is not made for the forgiveness of sins that the murderer had committed but only for cleansing the body itself (Heb 9:13).

The descriptions above of the instances in which ombunguhiro is performed clearly show that SJAHMCA performs ombunguhiro to thank God, to commemorate the fulfilment of the prophecy and the founder of the church, to recall the history of their church and to heal and cleanse the sick people spiritually and physically. In other words, SJAHMCA performs ombunguhiro as part of holistic healing by recovering and restoring broken relationships between the different people and powers believed to be involved in the daily lives of their members. For example, they might restore the relationships between a member and ancestors, family, community or the church. They might also protect that member from evil powers. As Kunnie (1992:3) says, the Herero want to be healed holistically.

\section{Procedure of ombunguhiro}

The procedure of the sacrificial ceremony for a sick church member or a patient is as follows:

- holding a personal consultation with the sick church member or a patient

- slaughtering the animal (otjipuka)

- removing the entrails (otjandja)

- burning some of the meat to smoke

- coming back to the church building

- eating some of the meat

- closing the ceremony by burning the bones

- quarantine (okuriapura).

The ceremony will be performed around the altar. However, most of the AICs in Namibia do not have a flat-topped altar built with solid bricks. In many cases, the place on the ground that is used as an altar, or where the altar is built, is fenced with any wire or thread available. The altar is usually located in the churchyard.

\section{Descriptions of the different parts of ombunguhiro}

Holding a personal consultation with the sick church member: When sick church members come to church, the prophet of the church holds a personal consultation with them. Then the prophet examines the church members and determines what kind of sickness they have. After examining the sick persons, the prophet prescribes them the proper animal that they must bring for the offering. Then the people follow the instructions. The animal that they have to bring will be subject to the level or the kind of illness from which they suffer. If it is extremely serious, the prophet requests them to bring a big cow. If the illness is less serious, a smaller kind of animal, like a goat or sheep, bird or chicken, or even foodstuff such as grain is requested.

Slaughtering the animal (otjipuka): When the animal has been brought to the churchyard, the appointed bishop or one of the church officials appointed by the Archbishop may slaughter the animal. Otherwise, any one of the laity slaughters the animal for the sacrifice according to the right procedure. Then the patient takes blood from the animal and washes herself or himself in any isolated place.

Removing the entrails (otjandja): After slaughtering the animal, the entrails, for example, the kidneys with the fat, are removed in accordance with Leviticus 3:1-17 and burned to smoke.

Burning some of the meat to smoke: An appointed church official burns some of the meat at the reserved altar. There is no specific firewood designated to burn the meat. Whilst the meat is burning, the smoke created by the burning of the meat forms a bridge between God and the sick person to be healed.

Coming back to the church building: When the sick person comes back to the church premises, the prophet prays for the sick person whilst sprinkling water onto this person. When the congregation visits the church, they also pray for the sick person.

Eating some of the meat: After that, all of the participants of ombunguhiro may share the meat with the congregation. This is for table fellowship. In the case of SJAHMCA, everyone, including the sick person, may eat the meat of the animal slaughtered there. Particular individuals are not allotted particular parts of the meat. Some churches, however, do not allow the sick person to have meat together with the others at that time.

Closing the ceremony by burning the bones: Burning the bones collected from the slaughtered animal indicates that the ceremony is closed. Participants may disperse and go home.

Quarantine (okuriapura): However, in accordance with 1 Samuel 10:8, the sick persons must take one more course of action: They must keep themselves in isolation at a certain place and wait for seven days until they have received an answer concerning the matter about which they prayed to God. This confirms that the sick persons have been healed as a member of their community and will not cause any problems for the community to which they belong. This period of isolation is similar to the period of isolation observed as part 
of the initiation practices of many African cultures (BrownWhale 1993:171-172).

According to Archbishop Pura of SJAHMCA, the main purpose of ombunguhiro is to thank God and to heal the sick. SJAHMCA does not sacrifice animals to expiate their sins. When an animal is sacrificed, the meat is shared with all the church members for table fellowship in Efeste. In this way, ombunguhiro forms part of a holistic healing ritual in SJAHMCA in a way that is acceptable in terms of the Bible and that is also acceptable from their unique cultural perspective.

\section{Herero culture}

To analyse how the AICs in Namibia have been influenced by the Herero culture, this section will focus on describing selected aspects of Herero culture such as the slaughtering of domestic animals, practices surrounding the sacred shrine (okuruuo) and their relationship with their ancestors (or ancestral spirits).

\section{Slaughtering domestic animals}

The lifestyle of traditional Herero people is semi-nomadic. They are herders. They erect a permanent settlement and herd the livestock around it. They are also cattle drivers. When the dry season comes, they start moving with the cattle so that the cattle can graze and drink in various places in Namibia. When the wet season comes, they return to their permanent settlement.

In their culture, animals are often slaughtered. However, they do not always slaughter their animals for food. This is due to the fact that the animals are considered to be their property. Kandovazu (1968:11-13), a Herero evangelist of the Evangelical Lutheran Church in Namibia, mentioned that there are specific occasions in Herero culture on which animals are slaughtered, for example funerals, marriages and births.

Whenever there is a funeral, for instance, they will slaughter some livestock. This is not only done so that meat can be served to the bereaved but also for ending the death ritual or wailing period of the bereaved. When they slaughter livestock, they sprinkle the entrails of the slaughtered animal into the wailing hut and at the sacred shrine (okuruuo) to end the funeral. Then the bereaved can start to eat the meat that was set aside for the wailing period. The entrails (tjandja) of the slaughtered animal are prohibited food. This ritual releases the bereaved from their sorrow and gives them serenity.

With regard to marriage, the bridegroom brings an ox, a ram and a ewe as dowry (ovitunja) to the parent of the bride. On the wedding day, they slaughter the ox for the feast. Then they take the stomach fat from the slaughtered ox and cover the bride with it. This is done to prevent the bride from encountering any misfortune.

If a father begets a baby boy, he slaughters a calf or a sheep for only the women to eat. Giving a person or a family some meat which has been specially prepared may indicate them as distinctive from others.

As a reference, when a Himba ${ }^{10}$ family slaughters cattle, a specific part of the meat, for example the dewlap from a slaughtered cow or ox, is prohibited as food for the ordinary Himba. Only the royal family, which is the family of the honourable traditional chief, may eat this part. ${ }^{11}$ They acquired the knowledge about each different body part of cattle from slaughtering domestic animals.

\section{Sacred shrine (okuruuo) ${ }^{12}$}

Okuruuo is a sacred place for the Herero and therefore not a place for anyone to come and act in whatever manner they want. Only the family priest is allowed to access the place and perform the necessary acts. The okuruuo is the place where the Herero meet their ancestors. Okuruuo is also a holy place where the Herero pray to God through their ancestors. Okuruuo can also symbolise the Herero's cosmology, which involves natural phenomena (Röhreke 1994:1-3). Most of the Herero people are given their names at the okuruuo. The okuruuo has a central place in the Herero's religious life and identity.

\section{Ancestors}

Ancestors occupy an important position in the lives of Herero people. Kandovazu (2009:54) mentions that Herero life has no meaning without the ancestors. Maboea (2002:1) also says that ' $[t]$ raditional African life is void and meaningless without the presence of the ancestors and supernatural power'. The Herero respect their ancestors. However, Tjijenda (2013:141), a Herero scholar, says that, '... as a Christian I am convinced that what we were doing was undoubtedly worshipping because we felt dependent on our ancestors in every area of life'. He means that what the Herero do to their ancestors amounts to more than just showing 'respect'. It amounts, instead, to 'worship'. The reason for this is that they ask their ancestors for rain, healing, blessing marriages, removing curses and protection (Tjijenda 2013:141). It seems that the Herero people do not only respect or venerate their ancestors but also worship them.

\section{However, Katambo ${ }^{13}$ says:}

10.The Himba is one of the tribes in Namibia. They reside in a north-western Namibian territory, which is called Kaoko, in the Kunene Region of Namibia. They still maintain
their traditions from the past. This tribe is originally from the Herero. The Herero say their traditions from the past. This tribe is originally from the Herero. The Herero say that the Himba have the 'same mother and the same father' as they do. They used to live in the Kaoko region together, and they acknowledge their shared origins. When the Herero left that part of the country and travelled to the central part of Namibia, the Himba people remained behind. The Himba still live in the same area and abide by their traditional culture with a semi-nomadic lifestyle (Kavar 2000:117). The Herero and Himba groups both speak the Herero language, and the Herero language is one of the Bantu languages. They are not only familiar with slaughtering cattle but also abide by traditional law, which was established by the tribe long ago.

11.K. Tjambiru, interviewed by Jinho Park, Ouakapawe, Etanga, Namibia, 15 February 2010.

12.S. Katupa, interviewed by Jinho Park, Ehomba, Namibia, 15 September 2008.

13.G. Katambo, interviewed by Jinho Park, Windhoek, Namibia, on 17 July 2014. He had been a former member of the Namibian Traditional Healers Association from 2004 until 2009. He is currently a church leader of St. John Apostolic Holiness Church of Africa in Windhoek, which is affiliated under Namibian Christian Apostles Church of Africa in Windhoek, which is affiliated under Namibian Christian Apostles
and Prophet Association (NACAPA). His current profession is a driver, working for a transportation company in Windhoek. 
The ancestors really do not have any role. What could be understood about the role of ancestors is that they [the Herero people] may ask their ancestors, whom they know very well about, and whom they know how they were living and interacting with God, to ask God to help them to solve their problem. Actually, they [the ancestors] are messengers without any controlling power against the assets of human lives. The ancestors do not have power to bless people. Through the ancestors, people are sending their message. They [the ancestors] are messengers only.

Ancestors have a very significant influence on the daily lives of Herero people in a practical sense. They are thought to control invisible evil and demonic powers. Herero ask for the help of their ancestors at the okuruuo.

\section{Herero traditional healing medicines ${ }^{14}$}

When African people have certain problems, for example bad luck, misfortune, the presence of any evil power, unemployment, problems at work, the presence of magic or a shadow or bad health, they go to traditional healers and diviners. The traditional healers then determine what advice and instructions to give the people to solve their problems. To solve the problems, some materials used in traditional medicines are used as healing substances. Each different material has its own function to solve a specific problem. Sometimes it should be combined with other materials for a specific problem or disease. The Herero are an African people that use traditional African medicine in this way.

\section{Herero traditional medicines and their usages}

There are various traditional medicines in Namibia. The San people have acquired knowledge about traditional medicines and their usages from elders of their community, from parents and from their own observation of certain ailments. Sometimes they acquire it by nature in an exigent experience of danger (Dan 2008:14-15). In the same way, the Herero people have learned about the medicinal value of plants, animals and a few chemicals. Although medical science has achieved appreciable knowledge and produced many medicines through science in the 21st century, the traditional healer, herbalist, witchdoctor and soothsayer are well established in Herero traditional medicine. Their medicines and the usages of those medicines are listed below.

Kamangu: This herb can be found in the desert of Namibia. For many generations, this herb has been used by the Herero people to medicate themselves for various diseases like flu, malaria, tuberculosis and stomach problems. It is adopted as an antibiotic. It is also used against problems caused by rheumatism. It is cooked in hot water, and the people in need of help then drink the infusion. It does not matter what container is used for boiling the infusion. The people who are being treated do not have to worry about the dosage

14.J.T. Tjiueza, Interviewed by Jinho Park, Windhoek, Namibia, 02 August 2014 JT Tiiueza is a prominent specialist in Namibia, who is currently the Chairperson J.T. Tjiueza is a prominent specialist in Namibia, who is currently the Chairperson of the Namibian Traditional Healers Association (NTHA), registered under the Ministry of Health and Social Service in the government of Namibia as Namibia Traditional Council (NTC) in the Ministry of Primary Health Care Division 2014. H has mentioned six important herbs and substances used in traditional medicine that Herero traditional healers used to make use of to heal people in a traditional way in the past. because it is a natural innocuous herbal medicine. It does not matter how much of the infusion the person drinks in a day in order to be healed. The dosage depends on how serious the disease is, how far the disease has developed and how long the person has been suffering from it.

The scientific name of Kamangu is harpagophytum procumbens. It is also well known as 'Devil's Claw'. It belongs to the family of Pedaliaceae distributed in Namibia, Botswana, South Africa, Angola, Zimbabwe and Mozambique (Wynn \& Fougere 2006:535).

Inyamazani: This is a mixture of various herbs and ocean animals and fish. It is a greasy substance. Traditional healers may put a small portion of it onto charcoal and burn it. Then the inyamazani can be inhaled as smoke. When it starts smoking, the person who is being treated kneels down and inhales the smoke to chase the evil spirits away. These evil spirits cause all kinds of bad luck for the people, for example not being married, being unemployed, trouble with a boyfriend or girlfriend, barrenness or being prevented from making progress in some area of their lives. Only prophets, predictors or people working with the spirits of the ancestors can use inyamazani.

Ombepo branches: These are used by both the traditional healers and the people who consult them. When the mediums, predictors and prophets are unable to predict or when the pictures of predicting that they see remain unclear, they cannot establish the cause of the person's trouble or illness accurately. Then the predictors give the sick person the smoke of the ombepo branch so that the spirit of the ancestors or any spirit can be stirred to move progressively inside the person to tell the predictors or prophets something, for example what had happened to the person previously and what the person has to do to solve his or her problems. They may then make use of it to determine the causes of the problem and to give a remedy to the sick person. Healing can then be resumed. This is how the ombepo branch functions throughout the healing process.

Holy oil: Olive oil is usually used as holy oil. Traditional healers give this oil to people suffering from all sorts of different complaints caused by bad luck or evil spirits. This oil is mixed with water, and the people receiving treatment then bathe themselves with this water.

Omumborombonga: This is a tree, which is available in the northern parts of Namibia such as Ovambo land and Kaoko land. The traditional healers cut branches from the omumborombonga tree and put them on the fire. When they have been burnt enough on the fire, the healers take the ash of the omumborombonga from the fire. This ash is one of the holy ashes, which is mixed with water and used to bathe people who are receiving treatment as a cure for all sorts of complaints. Since the ash of the omumborombonga is considered holy, traditional healers may also give it to patients who are suffering from bad luck in order for them to escape any evil influences that might be causing their bad luck. 
Holy ashes: Traditional doctors, spiritual healers or faith herbalists use this kind of traditional medicine. They collect all the bones from cattle that have been sacrificed for the sick. They burn those bones in the fire. After burning the bones, and when the ashes are cool, they collect all the ash from the bones. They mix the ash with salt from the ocean and give it to the sick to bathe in. This appears to work for those people suffering from bad luck, being unwed, unemployed, having no boyfriend or girlfriend, barrenness or being prevented from making progress in some area of their lives. Those who do not recover when they are in need of help will also bathe in water mixed with this ash.

\section{Conclusion}

African traditional religion (ATR) has a very significant influence on the daily lives of Africans in a practical sense and involves ancestors and invisible powers such as ancestral power, evil power, demonic power and magic power. The major parties involved in ATR are their supreme being as source of life-giving power, the Africans themselves as carriers of African cosmology, the ancestors as agents of their supreme being, the traditional healer or medicine man as the one who examines the causes of catastrophes, sorcerers and witches as magic operators, diviners who read the divine constellation and interpret the cause of problems and demons or evil powers as sources of all kinds mishaps (Maboea 2002:1).

SJAHMCA and SJAFMN, however, in principle, do not have any relationship with traditional healers, diviners, sorcerers and witch doctors in Namibia. Both SJAHMCA and SJAFMN perform rituals and healing ceremonies upon the basis of what is written in the Bible. Whatever rituals or ceremonies the church performs, their aim is to keep the Bible as it is. Nevertheless, they do engage with the spiritual and invisible elements recognised by the ATR like shadows, evil spirits and bad luck, the unclean beings that are present in the lives of the members of SJAHMCA. The churches also apply traditional materials to cleanse their members and remove the influence of these unclean beings. However, one thing that must be kept in mind is that both the AICs researched in this article fundamentally do not agree with or employ the principles according to which the ATR and the traditional healers heal the sick. Although the church employs the same materials, they use those materials on the basis of biblical guidance. They never neglect to pray in the name of Jesus Christ for healing the sick by his power and to give all the glory to the Lord Jesus Christ. This is how SJAHMCA heals, and it is very different from the practices of the traditional healers. In this regard, the substance of both SJAFMN's and SJAHMCA's healing is very different from the healing principles of ATR and African culture.

NAICs, such as SJAHMCA and SJAFMN, are now struggling to defend their identity as a church and the identity of their ministries, which include their healing ministries. On the one hand, they have to distinguish themselves from ATR. On the other hand, their ministries have to remain acceptable in terms of African culture. It seems that the church is performing African traditional and cultural activities in their church ministry. However, rituals like ombunguhiro (animal sacrifice), per se, do not confirm any relationship or continuity with the ATR and African culture in its principles and purposes. Practices such as these are only similar to the practices of ATR in terms of their external aspects: the procedures and materials used for healing. One very gripping fact that has emerged from this investigation is that it seems that, although this church could not sever itself completely from African ideas, it does perform rituals based upon what is written in the Bible. Pura himself, in particular, as the Archbishop of SJAHMCA, does not willingly perform rituals that are not, according to his view, prescribed by the Bible. Neither SJAHMCA nor SJAFMN would willingly besmirch their identities as Christian churches. Although SJAHMCA continues to perform its rituals, which are ostensibly similar to the rituals of the ATR and African culture, the churches never perform rituals with a similar purpose or directed at the same spiritual entities, as is done in the rituals of ATR. The rituals of these churches are instead based upon their reading of the Bible. Nevertheless, there is still an assignment that the SJAHMCA has to complete, and that is with regards to the way in which they should read and apply the contents of the Bible in their church ministry with continuity and historicity between the Old and the New Testaments. Tjijombo ${ }^{15}$ says the following:

The ancestors have no authority and ability to control anything for the living in the world as all authority belongs to God only. Neither do they have a throne, for heaven is God's throne.

\section{Acknowledgements Competing interests}

The authors declare that they have no financial or personal relationships which may have inappropriately influenced them in writing this article.

\section{Authors' contributions}

S.T.K. (University of Pretoria) was responsible for the conceptual framework and contribution as well as for the missiological insight and supervision of the project. J.P. (University of Pretoria) was the researcher responsible for the implementation of the research project and writing the findings.

\section{References}

Amanze, J., 1994, Botswana handbook of churches: A handbook of churches, ecumenical organisations, theological institutions, and other world religions in Botswana, Pula Press, Gaborone.

Anderson, A., 2000, Zion and pentecost: The spirituality and experience of pentecostal and Zionist/Apostolic shurches in South Africa, University of South Africa Press, Pretoria.

Breure, J., 1999, 'Ancestors: A challenge to the Oruuano Church of Namibia', MTh dissertation, Dept. of Missiology, University of South Africa.

Brown-Whale, R.E., 1993, Africanizing worship in the mission churches of Africa, School of Theology, Claremont.

15.P.K.U.D. Tjijombo, interviewed by Jinho Park, SJAFMN, Windhoek, Namibia, 13 August 2014. Tjijombo is totally reliant on God and his miraculous power according to Psalm 103:3 
Buys, G.L. \& Nambala, S.V.V., 2003, History of the church in Namibia 1805-1990: An introduction, Gamsberg Macmillan, Windhoek.

Dan, V., 2008, 'A study of traditional medicine usage by the San: The case of farm six', Analyses and Views 2, 1-20.

Dube, L, Shoko, T. \& Hayes, S., 2011, African initiatives in healing ministry, Unisa Press, Pretoria.

Kandovazu, E., 1968, Orruano rua pita vi?, Rynse Sending-drukkery, Karibib.

Kandovazu, E., 2009, The origin and history of the Oruuano Church in Namibia, Klaus Hess Publishers, Windhoek.

Kavari, J.U., 2000, 'Orature in Kaoko: Poetry and prose of Ovaherero and Ovahimba', in G. Henrichsen \& D. Henrichsen (eds.), New notes on Kaoko: The northern Kunene region (Namibia) in texts and photographs, pp. 473-500, Basler Afrika Bibliographien, Basel.

Kunnie, J., 1992, 'Indigenous African churches and religio-cultural liberation: The practice of traditional healing', paper presented at the African Studies Association, Seattle, Washington, 05 November, pp. 1-15.

Maboea, S.I., 2002, The influence of the life-giving power in the African traditional religion and the Zioninst churches, CB Powell, Pretoria.
Namibia 2011 population and housing census main report, 2015, viewed 18 February 2015, from http://www.nsa.org.na/files/downloads/Namibia\%202011\%20 Population\%20and\%20Housing\%20Census\%20Main\%20Report.pdf

Prozensky, M. \& De Gruchy, J. (eds.), 1995, Living faith in South Africa, David Philip, Cape Town.

Röhreke, A., 1994, 'An investigation concerning the origins of the Herero holy fire in myth and rite, and its relation to pastoral ideology', in C. Fiamingo (ed.), Symposium: Writing history, identity and society in Namibia: Collected papers, University of Trieste, Trieste.

Thomas, L.E., 1997, 'Survival and resistance in an African indigenous church', Journa of Theology for Southern Africa 98(I), 13-20.

Tjijenda, T.S., 2013, 'Mission history: Carl Hugo Hahn and the spiritual condition of the Herero-Mabanderu people', in T. Prill (ed.), Mission - Namibia: Challenges and opportunities for the church in the 21st century, pp. 8-9, GRIN, Norderstedt.

Turner, H.W., 1979, Religious innovation in Africa: Collected essays on new religious movements, G. K. Hall \& Co., Boston, MA.

West, M., 1975, Bishops and prophets in a black city: African independent churches in Soweto, David Philip, Cape Town.

Wynn, S.G. \& Fougere, B.J., 2006, Veterinary herbal medicine, Mosby, St. Louis, MO 